\title{
Yield of fodder oat and balance sheet of nutrients influenced by tillage practices and nutrient management
}

\author{
SAHAJA DEVA \\ Department of Agronomy, Indira Gandhi Krishi Vishwavidyalaya, RAIPUR (C.G.) INDIA \\ (Email : sahajareddy.deva@gmail.com)
}

\begin{abstract}
A field experiment was conducted during Rabi, 2011-12 to study the effect of tillage practices and nutrient management on growth, fodder yield and quality of oat (Avena sativa $\mathrm{L}$.). The treatments comprised of zero tillage, minimal tillage and conventional tillage in main plots and 75 per cent RDF, 75 per cent RDF + bio-fertilizers, 100 per cent RDF, 100 per cent RDF + bio-fertilizers in sub plots. Biofertilizers are Azotobacter and phosphorus solubilizing bacteria. Highest green and dry fodder yields were recorded in the plots treated with conventional tillage. Highest net available soil nutrients were recorded under plots treated with conventional tillage. In case of nutrient management highest green fodder and dry fodder yields and highest net available soil nutrients were recorded in the plots treated with 100 per cent RDF + biofertilizers (Azotobacter and PSB).
\end{abstract}

Key Words : Oat, Tillage, Nutrient management, Biofertilizers, Yield, Balance sheet

View Point Article : Deva, Sahaja (2015). Yield of fodder oat and balance sheet of nutrients influenced by tillage practices and nutrient management. Internat. J. agric. Sci., 11 (1): 112-115.

Article History : Received : 18.08.2014; Revised : 18.11.2014; Accepted : 04.12.2014 